\title{
Namibia : the Ideology of National Liberation
}

\section{Kimmo Kiljunen}

We in SWAPO have come to the realisation that the decisive factor in our liberation struggle, now and in the future is the conscious participation of the people. By conscious participation, we mean a deep-going process of debate, criticism and selfcriticism, that we are in the struggle to put an end to the exploitation of man by man in our society; that we are in the struggle to put an end to all forms of ethnic or national oppression; that we are in the struggle to make the toiling masses of Namibia, the workers and peasants, have direct access to the means of production; and that we are in the struggle to open wide all the doors to all the educational and cultural institutions to all Namibia people without regard to race, sex, colour or ethnic origins.

[Nujoma 1976]

\section{Introduction}

This paper examines the ideology of the South West Africa People's Organisation (SWAPO) as expressed in its public statements. It shows how this ideology has changed over time in response to changing circumstances. This ideology is related to SWAPO's goals for the society of independent Namibia. This paper, however, is not centrally concerned with the likely pattern of public policy after independence. ${ }^{*}$ This must depend on the circumstances in which liberation is obtained.

\section{Nationalism, Liberation, Social Aims}

The foregoing statement by SWAPO's President, Sam Nujoma, defines the specific nature of the national liberation struggle in Namibia. He emphasizes the need for consciousness. He puts forward goals of social equality and basic human rights, and stresses that to achieve them structural changes in society are needed. The objectives are not restricted to furthering the interests of any ethnically, regionally, sectorally or socially distinguishable group, but are nationwide. This differentiates his movement from separatist, tribalist or class-based forces and makes it a national movement. National consciousness does not prevent SWAPO from recognising the existence of social conflicts and contradictions; rather, Nujoma's statement emphasizes the need for their solution. The fact that President Nujoma stresses not national aims but social progress as

\footnotetext{
* See Green's article on Namibia in this Bulletin.
}

the basic criterion for SWAPO's action characterises SWAPO as not only a national movement but also a liberation movement.

In terms of national struggle, SWAPO's action is part of the general decolonisation process in the African continent. Its ideological roots and strategy are closely linked to the tradition of African nationalism, which provided the ideological framework for the general decolonisation of the continent in the late 1950 s and the early 1960 s. When analysing 'African nationalism' four dominant ideological components emerge: anticolonialism, Pan-Africanism and neutralism, national unity and egalitarianism.

Due to the lateness of national struggle in Southern Africa there are some new elements in the liberation theory and social analysis of the national liberation movements, drawn, at least partially, from the experiences of other African states during their first years of political independence. While other African countries had achieved formal political independence, dependence remained in structural, social, economic and cultural relations with the former colonial powers. Thus a new concept emerged: neo-colonialism. Kwame Nkrumah defined this as 'the process of handing independence over to the African people with one hand, only to take it away with the other hand' [Davidson 1971: 126].

Patterns of neo-colonial dependency were used by the liberation movement to explain why it had not been possible to provide an alternative to the present unequal international division of labour and to the consequent underdeveloped social structures in Africa. In reaction, there developed the strategic concepts of 'self-reliance', the fulfilment of basic human needs and the democratisation of social structures and institutions [Väyrynen 1978].

A social policy which emphasises these objectives has thus come to complement the framework of traditional African nationalism. Together, they imply three new ideological components: antiimperialism, mobilisation of both material and human resources, and social justice. Subsequently these concepts have served to define the nature of social development in the post-colonial societies. 


\section{From Anti-colonialism to Self-reliance}

The theory inherent in the process of national liberation in Southern Africa is manifested in SWAPO's Political Programme, adopted in August 1976 by the General Committee. The paragraphs defining the general political goals state:

The tasks before SWAPO at present and in the immediate future are

1 the liberation and winning of independence for the people of Namibia, by all possible means, and the establishment of a democratic people's government;

2 the realisation of genuine and total independence of Namibia in the spheres of politics, economy, defence, social and cultural affairs.

In order to achieve these goals, SWAPO has resolved:

1 to persistently mobilise and organise the broad masses of the Namibian people so that they can actively participate in the national liberation struggle;

2 to mould and heighten, in the thick of the national liberation struggle, the bond of national and political consciousness amongst the Namibian people;

3 to combat all manifestations and tendencies of tribalism, regionalism, ethnic orientation and racial discrimination;

4 to unite all Namibian people, particularly the working class, the peasantry and progressive intellectuals into a vanguard party capable of safe-guarding national independence and of building a classless, non-exploitative society based on the ideals and principles of scientific socialism.

[SWAPO 1976a]

SWAPO's political goals and strategy for action as articulated here, are nationwide; the movement remains faithful to the populist tradition in African nationalism. The Political Programme emphasises anti-colonial struggle to achieve national sovereignty. The objective is to create a unitary state in which the interests of different population groups and regions would be equally represented. The national movement is a common front combining the separate interests of different classes, social strata and social groups.

At the same time SWAPO's general socioeconomic goals include social liberation, in the form of a strategy of self-reliance:

- in addition to political changes, social restructuring is required to abolish all relations of external domination, ie anti-imperialism;

- to realise 'genuine and total independence', and to form 'a democratic people's govern- ment' it is vital to organise the mass of the population and to raise general consciousness; ie mobilisation:

- in a widespread liberation struggle involving different sections of the population with the workers and peasants actively engaged, the objective of social reform becomes a 'classless, non-exploitative society', ie social justice.

It is clear that SWAPO's programme is socialist in character despite the fact that the word 'socialism' appears in the party programme only in the section quoted above. In fact, it is more akin to main bodies of socialist thought and practice than several other ideologies or party manifestations that are classified under the label of 'African socialism'.' However, 'African socialism', 'socialism in Africa', and the socialist-oriented policies of the liberation movements - including FRELIMO and MPLA - of Southern Africa have one common feature. Their social analysis and strategy for action are based on local social and economic conditions. 'The main burden for the liberation of Namibia rests solely on the Namibians and on their ability to understand their own society' [Hall 1970: 23].

\section{Panafricanism and Neutralism}

SWAPO's progamme strives:

to foster and stengthen the anti-imperialist unity amongst the national liberation, world socialist, progressive and peace-loving forces in order to eliminate all forms of imperialism, colonialism and neo-colonialism.

The panafricanism of the early 1960s similarly stressed solidarity and the need for unity. Its slogan was 'Africa for the Africans' and it emphasised the similarity of problems in the continent. These were based on the struggle against the 'joint enemy', colonialism and white supremacy. SWAPO leans on this tradition and aspires:

to support and promote the ideals of unity of Africa as provided for in the Charter of the Organisation of African Unity:

to work in close cooperation with all progressive governments, organisations and popular forces for the total emancipation of the African continent.

[SWAPO 1976]

\footnotetext{
'African socialism' has been specifically rejected by Angola, Mozambique, Algeria, Ethiopia, Somalia, Guinea, Guinea Bissau and Tanzania. This is partly a reaction to its application to a particularly inegalitarian capitalist dynamic (Kenya), and to a system combining external capitalist dependence, a secondary state capitalist sector and major bureaucratic and neo-feudal elements (Senegal). It is therefore a highly confusing term since different authors apply it in very different ways.

2 Sekou Touré's term, and one more acceptable to most Africans who reject the concept of 'African socialism.'
} 
The idea of a United States of Africa, vigorously sponsored especially by Nkrumah, never came to fruition. Instead, the Organisation of African Unity (OAU) was established. While supporting the philosophy of 'live and let live', in respect to independent states, the OAU has remained radical in outlook toward the remaining colonial territories, and has given positive support to the liberation movement.

A logical step from panafricanism has been the struggle for neutralism and non-alignment. 'Africa should be free of all foreign military bases, nuclear and atomic testing facilities, and foreign military missions or pacts ... The foreign policy of African countries should in any case be guided by the principles of a most rigorous positive neutralism' [Davidson 1971: 58]. This was stated by African leaders in 1963 when seeking a basis for African unity. Stressing neutrality and unity was essential to demonstrating the reality of newly achieved political independence.

In the same tradition, SWAPO's foreign policy emphasises non-alignment and avoids involvement in conflicts between the super-powers.

SWAPO Government will adopt a posture of neutrality and non-alignment enjoying friendly relations with all nations. We are PanAfricanists, so we'll play a very active part in the $O A U$ and will promote the objectives of closer economic cooperation and continental political unity.

[Nujoma 1976]

\section{Egalitarianism and National Unity}

Another central ideological component of African nationalism has been the demand for equal rights: the desire for personal emancipation. Throughout the colonial period, Africans have experienced discrimination in political, economic, social and cultural life, supported by the insistent ideology of natural white supremacy. "Nationalism in Africa was primarily a claim for equality of status and of rights, for personal dignity, self-respect and full participation in the things of the material and spiritual world' [Davidson 1971: 58]. In Namibia, inequality is sharply highlighted by the fact that the South African white minority government pursues statutorily enforced racial discrimination. For many people in Namibia the liberation struggle means before all else a struggle against racism and the system of white privilege.

South African colonial rule has drastically changed earlier social conditions and structures, to which it is impossible to return. Nor is the South African policy of 'separate development', which tries to revive tribal segregation by forming 'Bantu homelands' and tribally based nations, a real alternative. Instead, one has to start by acknowledging that;

all of Namibia's tribal communities have been brought under the colonial order and thus suffered common oppression. This common oppression has dialectically shaped among those people a sense of collective destiny as a nation.

[SWAPO 1976b: 9]

In 1975 SWAPO published a discussion paper setting out possible elements of a constitution for independent Namibia. Defining central principles of the new constitution, the document states:

SWAPO has, over many years, repeated its essential conception of Namibia as an independent, unitary state. The borders of our territory are those of 'South West Africa', including Walvis Bay. Our experience of persecution and racialism over many years has deepened our unqualified commitment to democratic rule, the eradication of racialism, the establishment of the rule of law and the entrenchment of human rights. Moreover, we reject absolutely any notion of bantustans masquerading as federalism.

[SWAPO 1975 para 42]

The draft gives SWAPO's most detailed and concrete ideas to date on the administration of a future Namibia. According to the paper, the political system would be based on the principle of parliamentary democracy. Namibia would be a republic with a president with strong executive powers as the head of state. It is suggested that a single-chamber 100-member legislative parliament would be adequate, without excluding the possibility of an advisory second chamber consisting of traditional tribal chiefs. An independent judicary and an impartial public service would guarantee minority rights. The cabinet would have a minister responsible for human rights, and a Complaints Commissioner would handle complaints about public administration. English would be the official language and Namibia would apply for membership of the Commonwealth [United Nations Institute for Namibia 1979].

These constitutional proposals reflect western principles of political democracy, and SWAPO's efforts to gain national and international support for its programme. However, the document is not very precise as to the role of the national liberation movement, the position of the political opposition, or the status of the lower level representative organs, such as people's commitees, in an independent Namibia. 


\section{Social Basis of the Liberation Process}

It is important to differentiate between the concept of national liberation and that of social liberation [see Cabral 1974b: 82-3], by examining which social strata form the leading elements in the anticolonial struggle. Each liberation movement reflects the specific conditions of its own country. Thus neither the vanguardism of a marxist-leninist proletarian party nor the western democratic multiparty system has been able to provide a model for national liberation. What is required is a new type of political organisation: multi-class, united and nationwide. In these terms, a liberation movement is the expression and embodiment of national unity in the struggle for independence.

Although some barriers. to cooperation between different tribes, regional and social groups have been broken down, the Namibian people cannot be seen as monolithic, without internal conflicts. SWAPO's liberation theory does not imply belief in a conflict-free society, or in Africa's 'classlessness' - notions which had been typical of earlier phases of African nationalism. On the contrary, it recognises social stratification and the attendant conflicts of interests within the united front, and realises that although they might not be explicit in the early stages of national liberation, they will emerge during the period of reconstruction.

The composition of a national liberation front and the position of different groups in it reflect the country's social structure, the level of consciousness of different social groups, and their positions in the colonial administrative machinery. The need 'to unite all Namibian people, particularly the working class, the peasantry and progressive intellectuals' is emphasised in SWAPO's programme. This expresses the general orientation of the Namibian Liberation Front; firstly, against foreign, colonial domination and secondly, against internal inequalities and social subordination. As is typical of a national movement, there is no deeper analysis of social relations and the significance of different social groups in society - at least not in externally oriented manifestos.

The process of national liberation in Namibia was launched by young, educated activists who had moved to urban areas. Some were contract labourers but others were school-teachers or clergy. The young intellectuals and middle-class do not however represent a sufficiently broad economic or social base to seize power. They have to identify with the masses in order to mobilise an effective and widespread national liberation struggle. Nevertheless the intellectuals have played a significant role as instructors, organisers and leaders, especially in the first phase of the struggle [Cabral 1974a; Amin n.d.].

The success of the liberation movement in Namibia has been based essentially on its ability to make the interests of workers and peasants ${ }^{3}$ all over the country its own interests and thus to mobilise popular support. Those movements and organisations in Namibia which have been led by the traditional elite (NUDO, Damara Tribal Executive, Nama Chief's Council, etc.), or have limited themselves to fostering the interests of some specific social or ethnic group (Rehoboth Baster Verening, Rehoboth Volksparty, The Voice of the People Party, Demcop, NAPDO), or have remained merely organisations of a narrow group of students and of political refugees abroad (SWANUF, and, beyond the special case of Herero land rights, SWANU) have thus not been able to become leading forces in the liberation process. SWAPO's success, on the other hand, can be explained by the fact that:

- its operation were originally mainly carried out inside Namibia and it has retained a broad network of branches and activists within the territory;

- it has been capable of uniting people of different ethnic or regional origins, and religious affiliations or beliefs into a cohesive, national organisation;

- from its early beginnings, it found support not only among the intellectuals and the middle class but also, and most important, among urban (contract) workers and rural peasants.

The mobilisation of the population has, in addition to national objectives, strengthened social aims, since the objectives of the liberation movement have been founded on the needs and aspirations of the poor. Thus SWAPO was able to create a social basis for a successful struggle supported by the majority of the population.

\section{Social Objectives of National Liberation}

What, then, is meant by identification with the interests of the majority of the people and what are the main policy issues in independent Namibia? During the course of the liberation struggle the social objectives of the liberation movement have been refined. SWAPO's first political programme, dating from 1960, emphasized the right to selfdetermination and to political equality. The transformation process was seen primarily as

\footnotetext{
${ }^{3}$ Because of the contract labour system the most politically conscious workers are past and future peasants.
} 
political liberation, and consequently equal human rights and political freedoms were emphasized: 'universal adult suffrage', 'full equality of rights and responsibilities', 'freedom of speech, press, assembly, and religion', etc.

It would be wrong to assume that SWAPO no longer subscribes to these goals, but over time the emphasis has shifted from political liberation to social emancipation. The major objectives are social justice, nationwide economic progress, and popular participation in social decision-making. The 1976 Political Programme states the aspirations of an independent Namibia as follows:

- wage the struggle towards the abolition of all forms of exploitation of man by man and the destructive spirit of individualism and aggrandisement of wealth and power by individuals, groups or classes;

- ensure that all the major means of production and exchange of the country are under the ownership of the people;

- strive for the creation of an integrated, national economy in which there is a proper balance between agricultural and industrial developments by establishing a processing industry; a comprehensive agrarian reform aimed at giving land to the tillers; peasants' or farmers' cooperatives or collectives; state-owned ranching and crop farms, aimed at making Namibia an agriculturally self-sufficient nation, and a spirit of self-reliance.

The SWAPO programme aims to increase social justice and to develop the skills, knowledge and cultural creativeness of the toiling masses'. The programme proposes an extensive campaign for 'work-oriented, functional literacy', free and universal education, and, in particular, urgent training of technical and professional personnel. The health programme emphasizes free medical services, effective preventive medicine and health education.

The realisation of SWAPO's political programme would thus imply profound social and economic reconstruction in Namibia. Does SWAPO stand a better chance of carrying out its programme than other African national movements?

\section{Social Mobilisation}

Many African countries achieved political independence relatively painlessly. They did not experience violent anti-colonial struggle. Broad national movements were often established but were not forced to refine their goals beyond the single word 'independence', nor was there any need to raise general social consciousness beyond creating the belief that political independence was possible. In many cases, the mere replacement of the European administration by African counterparts did not change the privileged position of the elite or prevailing economic power structures. New bureaucracies have been corrupted and both civil and military elites have often used harsh methods to suppress attempts to extend the liberation process.

Where the people were mobilised on a larger scale, over a longer period of time, and with a more articulated set of goals and perceptions in the anticolonial struggle, the independence movement became transformed into a liberation movement. In order to maintain and extend mobilisation, the political leadership had to tie the programme closely to the interests and aspirations of the people; this presupposed social changes together with political independence.

The South African colonial administration in Namibia has not been willing to make concessions. Therefore the national liberation process led by SWAPO has been based on the broadest possible political mobilisation. This fact has not, however, been taken for granted; its development has required continuous political work, and eventual progress towards national liberation depends on its success.

For political mobilisation to succeed, SWAPO's programme emphasizes, political understanding must be deepened among SWAPO supporters and the people alike. This is not an attempt from an isolated vanguard to lead the liberation process, but rather to show people the need to solve their problems themselves.

\section{Armed Struggle}

SWAPO holds the conviction that armed resistance to the South African occupation in our country is the only viable and effective means left for us to achieve genuine liberation in Namibia.

[SWAPO 1975]

In many parts of Africa, the experience of colonial wars and 'pacification' operations led to attempts to find peaceful solutions. These manifested themselves in quasi-pacifist ideologies, following the 'non-violent resistance' of Gandhi, or in tactics such as mass demonstrations or non-cooperation (see Review of Political Economy, no 4, 1975).

In these circumstances, conscious acceptance of armed struggle has been a difficult step: 
The brutal repressive policy of the South Africans caught us by surprise. We had thought that we should carry on our struggle with the peaceful methods used elsewhere in Africa. But our demonstrations, boycotts and strikes were met with brute force and many leaders of SWAPO were tortured and killed. At the same time our peaceful efforts on the diplomatic front were frustrated by the inactivity of the $U N$.

[Nujoma 1976]

SWAPO itself was a non-violent organisation, but the South African Government is not truly interested in whether opposition is violent or non-violent. It does not wish to hear any opposition to apartheid. Since 1963 SWAPO meetings have been banned . . . We have found ourselves voteless in our own country and deprived of the right to meet and state our own political opinions. Is it surprising that in such times my countrymen have taken up arms? It was not an easy decision. Another man might have been able to say 'I will have nothing to do with that sort of thing'. I was not, and I could not remain a spectator in the struggle of my people for their freedom.

[Herman Toivo ja Toivo 1968]

The violence used by SWAPO is thus a direct response to the violence of the South African regime. Hence armed struggle is now part of the general political strategy of the movement.

However, much as we are convinced that armed struggle must now be the main form of our liberation activity, we do not beautify war as a purpose or regard it as a form of sport. We see war for what it really is - an extension of politics by other means. It is the continuation of political relations in the form of violence. But as in all other political relations one must seek to understand the nature of the politics being pursued ... As social relations, political acts are either just or unjust and just political acts are naturally to be supported.

[SWAPO 1976a]

As resistance has grown and the position of the regime weakened, South Africa has adopted new tactics. The violence of the regime has become more intense, widespread and overt. Guerrilla activities have led to mass arrests, brutal retaliation and victimisation. The South Africans hoped that the population would oppose the freedom fighters who were said to cause unnecessary suffering to civilians by continuing the guerrilla struggle. However, the violence of the government has strengthened the very challenge it had been designed to defeat. Those who until now, had been cautious or undecided, but who have been punished or threatened have been prepared to give full support to the resistance movement. The point has been reached where anything the government might decide to do against the liberation movement would weaken its own position: to reduce the scale of repression would facilitate progress by the movement; not to do so would fortify that challenge by expanding popular support. This has forced the regime to revise its tactics, and to attempt to find a false solution. In convening the Turnhalle talks, in organising general elections and in organising a 'National Assembly' it has apparently been forced to concede the basic demands of the national movement: political independence and African majority rule. Consequently for SWAPO, as the leading national force, this is a new situation. Mass support inside Namibia and world-wide political support until now have been based primarily on national demands, which are generally recognised. SWAPO's political programme has provided the framework for a strategy of national struggle. After Turnhalle and the beginning of a move toward what are made to appear as national institutions and independence, it will be necessary for SWAPO to specify even more clearly its social objectives, and hence to demonstrate the difference between a national movement and a national liberation movement.

\section{References}

Amin, Samir, (nd) The Class Struggle in Africa, Africa Research Group, Cambridge

Cabral, Amilcar, 1974a, Revolution in Guinea, an African People's Struggle, Imprimerie Jos. Adam, Brussels

- 1974b, in Lars Rudebeck, Guinea-Bissau: a Study of Political Mobilisation, Scandinavian Institute of African Studies, Uppsala

Davidson, Basil, 1971, Which Way Africa? The Search for a New Society, Penguin African Library

Hall, Richard (ed), 1970, South-West Africa (Namibia): Proposals for Action, The Africa Bureau, London

Nujoma, Sam, 1976, Statement at Dakar International Conference, January 5-8

- 1976, Interview by LSM News, Richmond, Canada, no $11-12$, pp 5, 15, 16 
SWAPO, 1975, Discussion Paper on the Constitution of Independent Namibia, mimeo

- 1976a, The Political Programme, Lusaka

- 1976b, 'On the content of the liberation struggle', Current Events in Namibia, no 7, p 9

Toivo, Herman Toivo ja, 1968, Statement in the Supreme Court in Pretoria, January 26
United Nations Institute for Namibia, 1979, Constitutional Options for Namibia: a Historical Perspective, Lusaka

Väyrynen, Raimo, 1978, Interdependence vs Self Reliance: Two Approaches to International Economic Relations, Research Report, no 16, Tampere Peace Research Institute

\section{Books Received}

Janet Abu-Lughod and Richard Hay Jnr (eds), Third World Urbanisation, Methuen, New York, 1979

Goran Hyden, Beyond Ujamaa in Tanzania: underdevelopment and an uncaptured peasantry, Heinemann, London, 1980

Deepak Lal, Prices for Planning: toward the Reform of Indian Planning, Heinemann, London, 1980

Appropriate technology information for developing countries, International Technical Information Network, US Department of Commerce, Washington, 1979

Demetrius S. Iatridis, Social Planning and Policy Alternatives in Greece, National Centre of Social Research, Athens, 1980

Nandini Joshi, Power versus Poverty: a View of UNCTADV, The New Order Book Company, Ahmedabad, 1980
J. Waddimba, Some participative aspects of programmes to involve the poor in development, United Nations Research Institute for Social Development, Geneva, 1979

Donald McGranahan, International Comparability of Statistics on Income Distribution, United Nations Research Institute for Social Development, Geneva, 1979

Third Progress Report on the Third National Development Plan 1975-80, Kano State Programme, Ministry of Finance and Economic Development, Kano State, 1980

Ernesto M. Pernia and Cayetano W. Paderanga Jnr, 'Urbanisation and Spatial Development in the Philippines: a Survey', Working Paper 7905, Philippine Institute for Development Studies, Manila, 1980 